\title{
Review Article: Lake and breach hazard assessment for moraine-dammed lakes: an example from the Cordillera Blanca (Peru)
}

\author{
A. Emmer and V. Vilímek \\ Department of Physical Geography and Geoecology, Charles University in Prague, Faculty of Science, Albertov 6, \\ 12843 Prague 2, Czech Republic \\ Correspondence to: A. Emmer (aemmer@seznam.cz) and V. Vilímek (vit.vilimek@natur.cuni.cz) \\ Received: 9 October 2012 - Published in Nat. Hazards Earth Syst. Sci. Discuss.: - \\ Revised: 2 April 2013 - Accepted: 3 May 2013 - Published: 18 June 2013
}

\begin{abstract}
Glacial lake outburst floods (GLOFs) and related debris flows represent a significant threat in high mountainous areas across the globe. It is necessary to quantify this threat so as to mitigate their catastrophic effects. Complete GLOF hazard assessment incorporates two phases: the probability of water release from a given glacial lake is estimated through lake and breach hazard assessment while the endangered areas are identified during downstream hazard assessment. This paper outlines a number of methods of lake and breach hazard assessment, which can be grouped into three categories: qualitative, of which we outline eight; semiquantitative, of which we outline two; and quantitative, of which we outline three. It is considered that five groups of critical parameters are essential for an accurate regionally focused hazard assessment method for moraine-dammed lakes in the Cordillera Blanca. These comprise the possibility of dynamic slope movements into the lake, the possibility of a flood wave from a lake situated upstream, the possibility of dam rupture following a large earthquake, the size of the dam freeboard (or ratio of dam freeboard), and a distinction between natural dams and those with remedial work. It is shown that none of the summarised methods uses all these criteria with, at most, three of the five considered by the outlined methods. A number of these methods were used on six selected moraine-dammed lakes in the Cordillera Blanca: lakes Quitacocha, Checquiacocha, Palcacocha, Llaca, Rajucolta, and Tararhua. The results have been compared and show that each method has certain advantages and disadvantages when used in this region. These methods demonstrate that the most hazardous lake is Lake Palcacocha.
\end{abstract}

\section{Introduction}

The term glacial lake outburst flood (GLOF) is used to describe the sudden release of water from a glacial lake (e.g. Benn and Evans, 1998; Clague and Evans, 2000). GLOFs have been studied in high mountainous areas across the globe, including the Himalayas (Kattelmann and Watanabe, 1997; Yamada, 1998; Quincey et al., 2007; Bajracharya et al., 2007), Karakoram (Hewitt, 1982), Hindu Kush (Iturrizaga, 2005; Ives et al., 2010), Tian Shan (Narama et al., 2010; Bolch et al., 2011; Engel et al. 2012), Pamir (Mergili and Schneider, 2011), Caucasus Mts. (Petrakov et al., 2007), Peruvian Andes (Reynolds, 2003; Vilímek et al., 2005a; Carey et al., 2012), Patagonia (Harrison et al., 2006; Dussaillant et al., 2009), Cascade Range (O'Connor et al., 2001), and British Columbia (Clague and Evans, 2000; Kershaw et al., 2005), as well as in the European Alps (Haeberli et al., 2001; Huggel et al., 2002) and Scandinavia (Breien et al., 2008).

GLOFs are characterised by a high transport and erosion potential (Cenderelli and Wohl, 2001; Breien et al., 2008) and, therefore, may convert rapidly into debris flows (O'Connor et al., 2001) with densities of about $1.5 \mathrm{t} \mathrm{m}^{-3}$ (Yamada, 1998). The maximal discharge may exceed $10^{4} \mathrm{~m}^{3} \mathrm{~s}^{-1}$ (Costa and Schuster, 1988), while volume of the transported material may exceed millions of cubic meters (Evans, 2002; Hubbard et al., 2005). GLOFs most commonly result from dynamic slope movements into the lake such as icefalls, rockfalls, or landslides (e.g. Costa and Schuster, 1988; Jiang et al., 2004; Awal et al., 2010). There are also other triggers including earthquakes (Lliboutry et al., 1977; Clague and Evans, 2000), intense rainfall/snowmelt (Yamada, 1998), the melting of buried moraine ice cores 
(Richardson and Reynolds, 2000b), the blockage of underground outflow channels (O'Connor et al., 2001; Janský et al., 2006), and the downstream propagation of a flood wave (Vilímek et al., 2005b). It is also possible for there to be no obvious dynamic cause, a phenomenon termed "dam selfdestruction" (Yamada, 1998). The likelihood of these various triggers, as well as the stability of moraine dam, has to be included in a precise hazard assessment (Richardson and Reynolds, 2000a; Hegglin and Huggel, 2008).

It is clear that GLOFs and related debris flows are significant geomorphic processes that represent a considerable threat to the inhabitants of high mountainous areas. These processes need to be studied thoroughly so as to mitigate their catastrophic effects or, ideally, to prevent them altogether (Silva and Caceres, 1995). It is, therefore, necessary to identify the potentially hazardous lakes and model flood scenarios so as to demarcate the endangered areas (Cenderelli and Wohl, 2001; Worni et al., 2012). The aim of this paper is to outline methods of lake and breach hazard assessment from moraine-dammed lakes and then to apply a number of these to six selected moraine-dammed lakes in the Cordillera Blanca of Peru. It is then possible to discuss the suitability of each method in relation to the regional specifics of this mountain range.

\section{Methodology}

The potential hazard associated with six moraine-dammed lakes is assessed in this study: these are the lakes of Quitacocha, Checquiacocha, Palcacocha, Llaca, Rajucolta, and Tararhua. They are all located within the basin of the Rio Santa, which ultimately drains into the Pacific Ocean (Fig. 1). These lakes were chosen for two reasons. First, they offer a range of divergent characteristics, which is important in order to identify differences between the various methods - three have natural dams (Quitacocha, Checquiacocha, and Tararhua) whereas three have dams with remedial works; some have a surface outflow (Checquiacocha and Tararhua) whereas others do not; some are in direct contact with a glacier (Palcacocha, Rajucolta and Llaca) whereas others are not. Second, the required data were readily available, from both remotely sensed imagery and fieldwork undertaken from May to July 2012 (at lakes Palcacocha and Llaca). The spaceborne and aerial images were used to obtain spatial information such as the distance between lake and glacier, the area of mother glacier, the amount of glacier shrinkage, and the identification of surface outflow. We also used published and unpublished reports from the archives of the Instituto Nacional de Recursos Naturales-Autoridad Nacional del Agua in Huaraz and the Instituto Geológico Minero y Metalúrgico of Peru in Lima. These data sources were used to obtain specific information such as the occurrence of piping through the moraine dam and bathymetric measurements. Table 1 presents a complete list of input data.

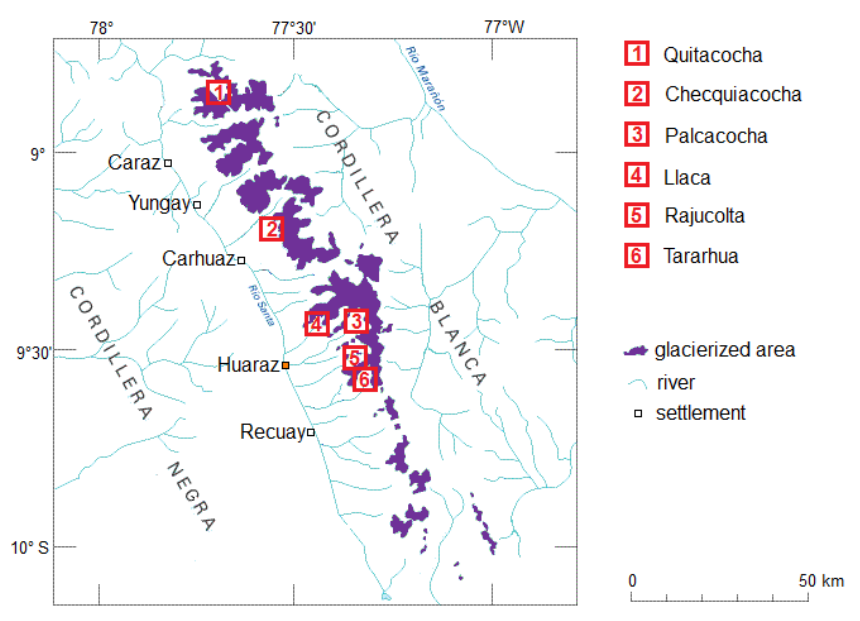

Fig. 1. The location of the selected lakes within the catchment of the Rio Santa in the Cordillera Blanca (base map: pubs.usgs.gov).

From the outlined methods we have used five of the qualitative methods to assess the six lakes listed previously. The potential hazard was defined by the number of negative parameters (parameters with a negative impact on the stability of a particular lake). The arithmetic mean of these results has been calculated. It is not possible to define which parameters are more important and, therefore, all carry the same weight. However, as certain parameters are repeated (e.g. distance between lake and glacier or contact with glacier), this clearly places greater weight on those stability parameters used by the greatest number of researchers. It was not possible to consider the stability parameter relating to the area of the mother glacier from the method presented by Wang et al. (2008) because no critical value is given for this parameter. The qualitative methods presented by Zapata (2002), Huggel et al. (2004), and Hegglin and Huggel (2008) were not considered because certain necessary critical values are not given and, therefore, the subjective component is too high. Semiquantitative method presented by Bolch et al. (2011) and quantitative method presented by Wang et al. (2011) were used according to original methodology described in Sect. 3. For determining whether ice cores are present within the moraine dam using airborne images, we used the method presented by McKillop and Clague (2007a). Unfortunately, it has not been possible to collect the required data for a complete method of hazard assessment. It was also not possible to use the method presented by Mergili and Schneider (2011) because we did not have enough data to calculate the topographic susceptibility index (TSI) and maximum peak ground acceleration (PGA).

\section{Approaches to lake and breach hazard assessment}

It is difficult to accurately assess whether water will be released catastrophically from a moraine-dammed lake. The 


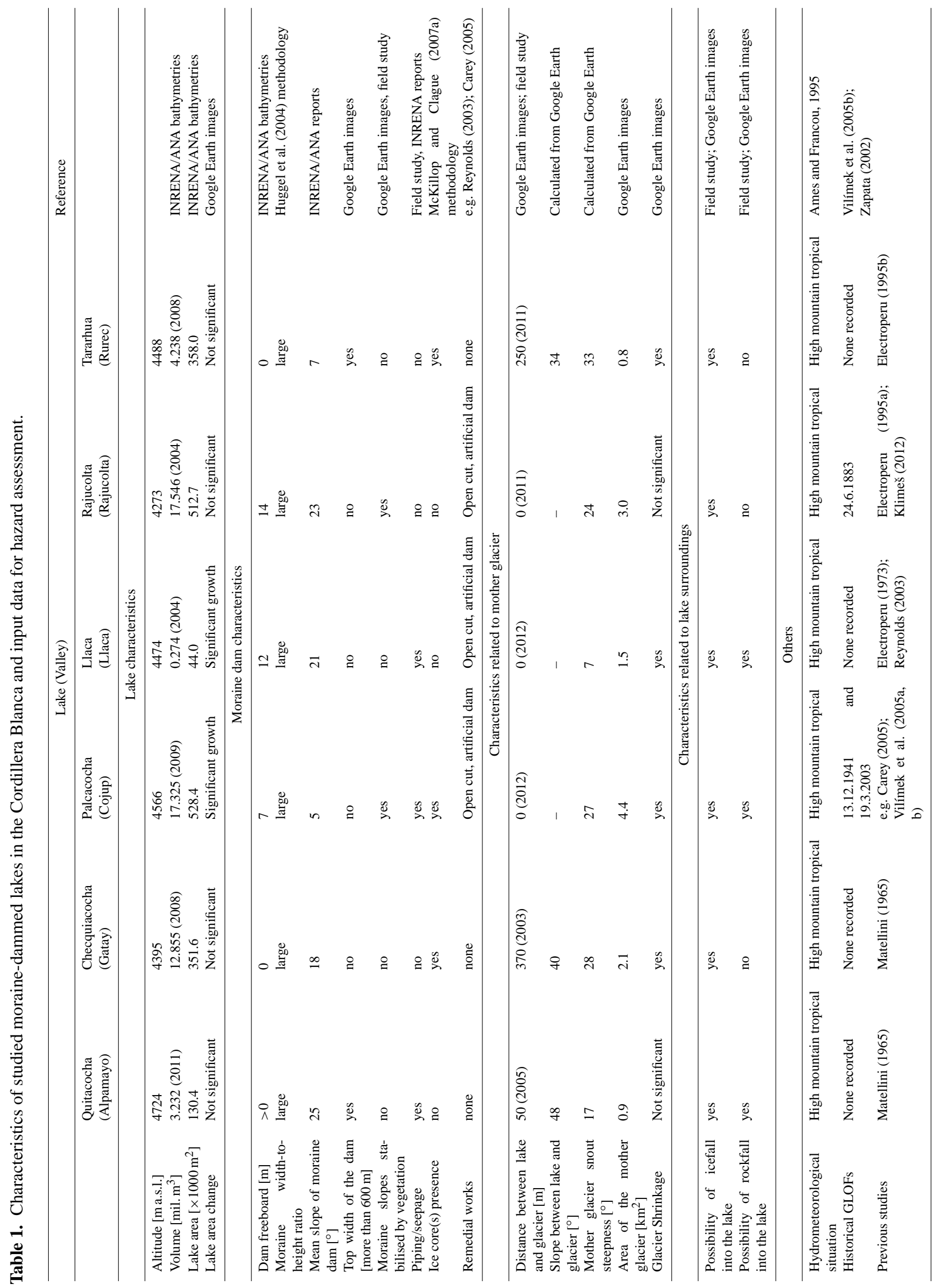




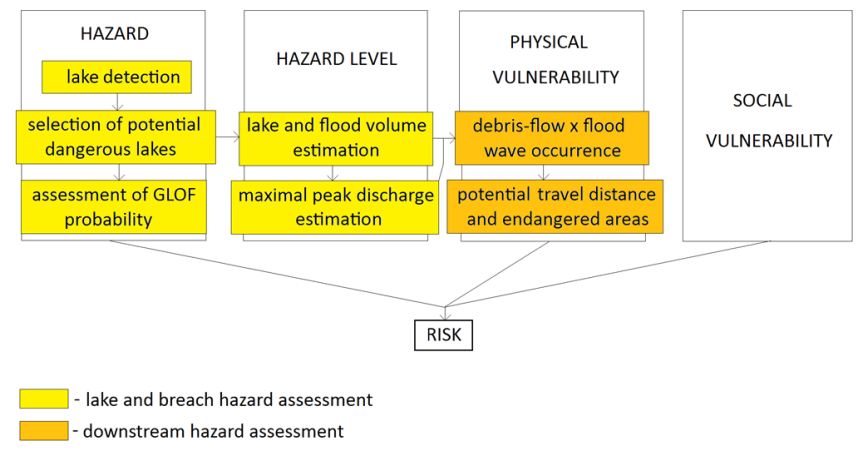

Fig. 2. The procedure for undertaking GLOF hazard, vulnerability, and risk assessment (Sources: Huggel et al., 2004; JTC1, 2004; Hegglin and Huggel, 2008; Richardson, 2010; Shrestha, 2010).

methods of lake and breach hazard assessment usually include two groups of parameters: the first considers the possibility of a triggering event while the second considers the dam stability (Richardson and Reynolds, 2000a; Hegglin and Huggel, 2008; Mergili and Schneider, 2011). It is, of course, possible that a flood may occur even if dam is thought to be stable.

In classic hydrology the flood probability may be derived from its frequency, but this cannot be used in relation to glacial lake outburst floods as they are usually one-off events (Van Steijn, 1996; Hegglin and Huggel, 2008). Clague and Evans (2000), O'Connor et al. (2001), and Huggel et al. (2004) define two stages of GLOF hazard assessment. The first identifies the potentially hazardous lakes and assesses the possibility of water release, the likely flood volume, and probable maximal discharge (i.e. lake and breach hazard assessment). The second examines the downstream hazard and assesses the probability of a debris flow, the reach of the debris flow, and the areas that may be endangered. These areas may then be classified according to their physical vulnerability. It is then possible to undertake a risk assessment for settlements and infrastructure in order to determine physical and social vulnerability (Fig. 2).

There are three approaches to assess the possibility of water release: qualitative; semi-quantitative; and quantitative. The methods are each based upon an evaluation of selected stability parameters (i.e. the stability of the moraine dam, the lake, the area adjacent to the lake, and the glacier feeding the lake). The various stability parameters are summarised in Table 2. It is clear that some parameters are repeated irrespective of the method with the most frequently considered being the distance between the lake and the glacier and the possibility of dynamic slope movements into the lake (e.g. icefalls or rockfalls). These represent the most frequent triggers of GLOFs worldwide (e.g. Awal et al., 2010). The other commonly considered parameters include the geometry of the dam, the freeboard-to-moraine crest height ratio, the moraine width-to-height ratio, and characteristics that describe internal structure of the dam (e.g. piping or the presence of an ice core).

\subsection{The qualitative approach}

In a qualitative approach, the stability parameters are normally assessed subjectively according to the experience of the individual researcher. The majority of the qualitative methods estimate those stability parameters that are thought to represent an increased hazard. The total number of qualitative parameters considered by those studies outlined here ranges between two and eleven (Table 2). These methods are generally used for preliminary hazard assessments in order to identify potentially hazardous lakes within large previously unstudied areas in which it is not possible to apply another approach. The simplest way to assess the potential hazard is to identify those characteristics indicative of increased hazard. For example, Clague and Evans (2000) showed that the probability of an outburst is high when the dam has a small width-to-height ratio, when outflow occurs mainly through seepage, when there is no armoured overflow channel, when the reservoir surface is normally close to the height of the dam, when there are highly crevassed glaciers clinging to steep slopes directly above the reservoir, and when the slopes above the reservoir are subject to rockfalls. Costa and Schuster (1988) outline four parameters while Grabs and Hanisch (1993) outline eleven parameters that suggest an increased hazard, while Zapata (2002) also introduced list of parameters for hazard assessment.

The simplest method for initially assessing GLOF hazard was presented by O'Connor et al. (2001). This examines only two stability parameters in order to assess the potential for moraine-dam breach, contact with a glacier and the dam freeboard (the vertical distance between the lake level and the lowest point of the moraine crest). These parameters have only two alternatives: "yes" or "no" for contact with a glacier and "high" or "low" for the dam freeboard; the latter is subjective as no critical value delimits "high" from "low". Moreover, this method only considers the most common cause of GLOFs, i.e. icefall into a lake producing surge wave. Nonetheless, four combinations with different aggregate hazards are possible (Table 3 ).

Huggel et al. (2004) used five stability parameters to obtain the qualitative probability of a GLOF (Table 4). Each parameter was assigned a probability (low, medium, or high), and the overall hazard was considered to reflect the highest probability level attained by any of the five parameters. The parameters were defined subjectively as no critical values were given, with the exception of dam width-to-height ratio. This method has been applied widely by others including researchers working in the vicinity of Mt. Everest (Bolch et al., 2008). In the Cordillera Blanca the method was broadened to include piping and existing remedial measures (Hegglin and Huggel, 2008). 
Table 2. The stability characteristics assessed in previous studies.

\begin{tabular}{|c|c|c|c|c|c|c|c|c|c|c|c|c|c|}
\hline Stability characteristic & 1 & 2 & 3 & 4 & 5 & 6 & 7 & 8 & 9 & 10 & 11 & 12 & 13 \\
\hline Armoured overflow channel (natural or technical) & & $\mathrm{x}$ & & $\mathrm{x}$ & $\mathrm{x}$ & & & & & & & & \\
\hline Buried ice present in moraine dam & & $\mathrm{x}$ & $\mathrm{x}$ & & & $\mathrm{x}$ & & $\mathrm{x}$ & $\mathrm{x}$ & $\mathrm{x}$ & $\mathrm{x}$ & & \\
\hline Compound risk present & & & & & & & & & $\mathrm{x}$ & & & & \\
\hline Crevassed glacier snout above lake & & $\mathrm{x}$ & & & $\mathrm{x}$ & & $\mathrm{x}$ & & & & & & \\
\hline Dam type & & & $\mathrm{x}$ & $\mathrm{x}$ & & & $\mathrm{x}$ & & & & & & $\mathrm{x}$ \\
\hline Debris-flow occurrence after GLOF* & & & & & & & & & & $\mathrm{x}$ & & & \\
\hline Distal flank steepness of the dam & & & & & & $\mathrm{x}$ & $\mathrm{x}$ & $\mathrm{x}$ & & & & $\mathrm{x}$ & $\mathrm{x}$ \\
\hline Distance between lake and glacier & $\mathrm{x}$ & $\mathrm{x}$ & & & & & $\mathrm{x}$ & $\mathrm{x}$ & $\mathrm{x}$ & $\mathrm{x}$ & & $\mathrm{x}$ & \\
\hline Evidence of recent small GLOFs & & $\mathrm{x}$ & & & & & & & & & & & \\
\hline Flash flood occurrence after GLOF* & & & & & & & & & & $\mathrm{x}$ & & & \\
\hline Glacier area & & & & & & & & $\mathrm{x}$ & & & & $\mathrm{x}$ & \\
\hline Glacier advance & & $\mathrm{x}$ & & & & & & & & & & & \\
\hline Glacier shrinkage & & & & & & & & & & $\mathrm{x}$ & & & \\
\hline Glacier snout steepness & & $\mathrm{x}$ & & & & & $\mathrm{x}$ & $\mathrm{x}$ & & $\mathrm{x}$ & & $\mathrm{x}$ & \\
\hline Hydrometeorological situation & & & $\mathrm{x}$ & & & & & $\mathrm{x}$ & & & & & \\
\hline Lake area & & & & & & & $\mathrm{x}$ & & & $\mathrm{x}$ & $\mathrm{x}$ & & \\
\hline Lake area change & & & & & & & & & & $\mathrm{x}$ & & & $\mathrm{x}$ \\
\hline Lake depth & & & & & & & $\mathrm{x}$ & & & & & & \\
\hline Dam freeboard & $\mathrm{x}$ & $\mathrm{x}$ & & & $\mathrm{x}$ & & $\mathrm{x}$ & & & & & & $\mathrm{x}$ \\
\hline Lake freeboard-to-moraine crest height ratio & & & $\mathrm{x}$ & $\mathrm{x}$ & & & & $\mathrm{x}$ & $\mathrm{x}$ & & & & \\
\hline Lake volume & & & & & & & $\mathrm{x}$ & & $\mathrm{x}$ & & & & \\
\hline Main rock type forming moraine & & & & & & & & & & & $\mathrm{x}$ & & \\
\hline Moraine height-to-width ratio & & & & & & & & & & & $\mathrm{x}$ & & \\
\hline Moraine slopes stabilised by vegetation & & & & & & $\mathrm{x}$ & & & & & & & \\
\hline Moraine width-to-height ratio & & & $\mathrm{x}$ & $\mathrm{x}$ & $\mathrm{x}$ & & $\mathrm{x}$ & $\mathrm{x}$ & & & & & \\
\hline Piping/seepage through moraine dam & & $\mathrm{x}$ & & $\mathrm{x}$ & $\mathrm{x}$ & & $\mathrm{x}$ & & $\mathrm{x}$ & & & & $\mathrm{x}$ \\
\hline Possibility of landslide/rockfall into the lake & & $\mathrm{x}$ & & & $\mathrm{x}$ & & $\mathrm{x}$ & & & $\mathrm{x}$ & & & $\mathrm{x}$ \\
\hline Possibility of dynamic slope movements into the lake (ice, rock material) & & & $\mathrm{x}$ & & & $\mathrm{x}$ & & & & & & & \\
\hline Possibility of snow/ice avalanche into the lake & & & & & & & $\mathrm{x}$ & & $\mathrm{x}$ & $\mathrm{x}$ & & & $\mathrm{x}$ \\
\hline Seismic activity & & & & & & & $\mathrm{x}$ & & & & & & $\mathrm{x}$ \\
\hline Slope between lake and glacier snout & & & & & & & & & & & & $\mathrm{x}$ & \\
\hline Slopes of lateral moraine/possibility of its fall into the lake & & $\mathrm{x}$ & & & & & & & & & & & \\
\hline Stagnant ice at the terminus & & & & & & & & & & $\mathrm{x}$ & & & \\
\hline Supra-/englacial drainage & & & & & & & & & $\mathrm{x}$ & & & & \\
\hline Top width of dam & & & & & & & & $\mathrm{x}$ & & & & & \\
\hline
\end{tabular}

1: O’Connor et al. (2001); 2: Grabs and Hanisch (1993); 3: Huggel et al. (2004); 4: Hegglin and Huggel (2008); 5: Clauge and Evans (2000); 6: Costa and Schuster (1988); 7: Zapata (2000); 8: Wang et al. (2008); 9: Reynolds (2003); 10: Bolch et al. (2011); 11: McKillop and Clague (2007a, b); 12: Wang et al. (2011); 13: Mergili and Schneider (2011). $*$ downstream hazard parameters.

Table 3. The qualitative probability of an outburst defined by O'Connor et al. (2001).

\begin{tabular}{lll}
\hline $\begin{array}{l}\text { Contact } \\
\text { with glacier }\end{array}$ & $\begin{array}{l}\text { Dam } \\
\text { freeboard }\end{array}$ & $\begin{array}{l}\text { Outburst } \\
\text { potential }\end{array}$ \\
\hline No & High & Low \\
Yes & High & Medium \\
No & Low & Medium \\
Yes & Low & High \\
\hline
\end{tabular}

Wang et al. (2008) used nine stability parameters with defined critical values to investigate two lakes in the Himalaya (Table 5) - these parameters and their critical values were based in part on the work of Lü et al. (1999). The parameters were selected if they were considered to offer a possible mechanism for breaching while the critical values were defined subjectively. It follows that a potential hazard exists whenever a given critical value is exceeded. A number of these values were again used in the qualitative method presented recently by Wang et al. (2011).

\subsection{The semi-quantitative approach}

In a semi-quantitative approach, the stability parameters are ascribed quantitative scores, but with a large degree of subjectivity. Reynolds (2003) used nine stability parameters (Table 2) with each assigned points according to its influence on the hazard: zero points if there is no impact, two points if there is a low impact, ten points if there is a moderate impact, and fifty points if there is a great impact. The overall hazard is 
Table 4. The qualitative probability of a GLOF defined by Huggel et al. (2004).

\begin{tabular}{|c|c|c|}
\hline Stability Characteristics & Alternatives & Probability of GLOF \\
\hline \multirow{3}{*}{ Dam type } & Bedrock & Low \\
\hline & Moraine-dammed & Medium to high \\
\hline & Ice-dammed & High \\
\hline \multirow{3}{*}{ Ratio of freeboard to dam height } & High & Low \\
\hline & Medium & Medium \\
\hline & Low & High \\
\hline \multirow{3}{*}{ Ratio of dam width to height } & Large $(>0.5)$ & Low \\
\hline & Medium (0.2-0.5) & Medium \\
\hline & Small $(0.1-0.2)$ & High \\
\hline \multirow{3}{*}{ Impact waves by ice- or rockfalls reaching the lake } & Unlikely, small volume & Low \\
\hline & Sporadic, medium volume & Medium \\
\hline & Frequent, large volume & High \\
\hline \multirow{3}{*}{ Extreme meteorological events (high temperature or precipitation) } & Unlikely & Low \\
\hline & Sporadic & Medium \\
\hline & Frequent & High \\
\hline
\end{tabular}

Table 5. The stability characteristics and their critical values defined by Wang et al. (2008).

\begin{tabular}{|c|c|c|}
\hline Stability characteristics & Critical value & References \\
\hline Top width of dam & $<600 \mathrm{~m}$ & Lü et al. (1999) \\
\hline Distal flank steepness & $>20^{\circ}$ & Lü et al. (1999) \\
\hline Ice-core presence & Yes & Richardson and Reynolds (2000b) \\
\hline Ratio of dam width to height & $0.1-0.2$ & Huggel et al. (2004) \\
\hline Glacier area & Not stated & Lü et al. (1999) \\
\hline Slope of glacier snout & $>8^{\circ}$ & Lü et al. (1999) \\
\hline Temperature and precipitation & High $T$, wetness High $T$, dryness & Lü et al. (1999); Huggel et al. (2004) \\
\hline Ratio of freeboard to dam height & 0 & WECS (1987) \\
\hline Lake-glacier proximity & $<500 \mathrm{~m}$ & Lü et al. (1999) \\
\hline
\end{tabular}

then obtained from the total number of points ( 0 : no hazard; 50: minimal; 100: moderate; 125: high; >150: very high). It was considered that an outburst could occur at any time if more than 100 points were recorded. In contrast to Wang et al. (2008), each of the parameters contributes to the overall hazard, irrespective of the fact that no critical values have been defined. However, due to the subjective assignment of points, this method cannot be classified as quantitative.

Bolch et al. (2011) used 11 weighted stability parameters in a study undertaken in Tien Shan. This method required the parameters to be selected, which was done partly on the basis of Huggel et al. (2004) and Bolch et al. (2008). The parameters were then ranked according to their probable influence on the occurrence of a GLOF. In this study the most important was thought to be change in lake area rather than the possibility of an icefall or rockfall (Table 6). The weighting followed a simple linear distribution rule (i.e. the second lowest weight is two times greater than the lowest weight; the third lowest is the sum of the second lowest plus the lowest weight and so on). The weights were multiplied by the value obtained from the assessed stability parameters. The overall hazard is derived from the total sum of these numbers with values of less than 0.1 representing very low hazard, 0.1-0.325 representing low hazard, 0.325-0.574 representing medium hazard, and greater than 0.574 representing high hazard. This method is different to others as it is not specifically a dam breach hazard assessment that aims to determine probability of flood occurrence. Instead, the downstream hazard parameters are also assessed: the occurrences of flash flood and debris flow following outbursts are used as variables in the calculation.

\subsection{The quantitative approach}

In a quantitative approach, the subjective elements in the hazard assessments are eliminated. McKillop and Clague (2007a, b) assessed hazard through an investigation of 175 moraine-dammed lakes in British Columbia, including 11 in which dams had been breached. In this statistical remote-sensing-based approach, 18 stability parameters 
Table 6. The selected stability characteristics and their weights defined by Bolch et al. (2011).

\begin{tabular}{lll}
\hline Stability characteristics & Weight & Alternatives \\
\hline Lake area change & 0.1661 & Shrinkage $(0)$ \\
& & Growth $<50 \%(0.5)$ \\
& & Growth $<100 \%(1)$ \\
& & Growth $<150 \%(1.5)$ \\
& & Growth $>150 \%(2)$ \\
& 0.1510 & Yes $(1) ;$ No $(0)$ \\
Possibility of ice avalanche into lake & 0.1359 & Yes $(1) ;$ No $(0)$ \\
Possibility of rockfall/avalanche into lake & 0.1208 & Yes $(1) ;$ No $(0)$ \\
Ice-cored moraine & 0.1057 & Could occur $(1) ;$ Could not occur $(0)$ \\
Debris flow & 0.0906 & Could occur $(1) ;$ Could not occur $(0)$ \\
Flash flood & 0.0755 & Yes $(1) ;$ No $(0)$ \\
Direct contact with glacier & 0.0604 & $<50000 \mathrm{~m}^{2}(0.5)$ \\
Lake area & & $50000-100000 \mathrm{~m}^{2}(1)$ \\
& & $>100000 \mathrm{~m}^{2}(1.5)$ \\
Glacier shrinkage & 0.0453 & Significant $(1) ;$ No $(0)$ \\
Glacier slope $<5^{\circ}$ at the terminus & 0.0302 & Yes $(1) ;$ No $(0)$ \\
Stagnant ice at the terminus & 0.0151 & Significant glacier velocity $(0) ;$ No $(1)$ \\
\hline
\end{tabular}

were considered. The results compared those lakes in which GLOFs had occurred previously to those in which they had not. Regression analysis showed that only 4 of the 18 stability parameters influenced the possibility of a GLOF: the moraine width-to-height ratio, the presence of an ice core, the lake area, and the main rock type within the moraine. Various alternatives of non-quantitative parameters are replaced by numbers in outburst probability calculation. The weights of these stability parameters were also calculated.

The calculated results $(\%)$ and related outburst probabilities are defined as follows: very low probability $<6 \%$; low probability $6-12 \%$; medium probability $12-18 \%$; high probability $18-24 \%$; and very high probability $>24 \%$. This method is essentially based on remote sensing with statistical analysis, although it is not possible to accurately determine the presence an ice core by these means. Therefore, certain morphological assumptions have to be made: a moraine with a rounded surface and minor superimposed ridges was considered to be ice-cored; a disproportionately large end moraine in front of a small glacier was suspected to be icecored, while a narrow sharp-crested moraine with an angular cross section was considered to be ice-free (McKillop and Clague, 2007a). It is also not possible to determine the main rock type from remotely sensed data, and so the available geological maps have to be used.

Wang et al. (2011) presented a quantitative method of lake and breach hazard assessment based on an investigation of 78 lakes in the southeastern Tibetan Plateau. In total five stability parameters were assessed (Table 7), although the input data only consider one cause of GLOF - icefall into a lake.
The stability parameters were chosen on the basis that they could be measured using the available remotely sensed data, that they acted independently, that the data type was continuous, and that they were consistent with those previously proposed for outburst lakes on the Tibetan Plateau (based on Lü et al., 1999). A fuzzy consistent matrix method was used to determine weighting of these stability parameters. The distance between the lake and glacier was found to be the most important characteristic with a weighting of 0.27 (Table 7). The threshold values were determined for each stability parameter using statistical distribution methods (median, 25th and 75th percentiles) based on the list of values derived from the 78 investigated lakes. The probability of an outburst was calculated as the sum of each individual indicator (see Table 7) multiplied by its respective weighting value. A result of less than 0.5 represents a low potential for outburst, 0.5 0.7 a medium potential, $0.7-0.8$ a high potential, and greater than 0.8 a very high potential for outburst flood.

Mergili and Schneider (2011) presented a remote-sensingand GIS-based method for assessing lake outburst flood hazard in the Pamir region. Eight parameters (Table 2), including lake type, were considered in order to estimate outburst susceptibility (four related to outbursts triggered by external forces and four related to outbursts triggered by internal forces). Critical values were given for all of the parameters (Table 8), and the subjective component is thereby eliminated. The susceptibility to outburst caused by either internal forces or external forces may range from 0 to 4 points $(-1,0,1$ or 2 points for each parameter) while the overall 
Table 7. The assessed stability characteristics, their weighting, and threshold values defined by Wang et al. (2011).

\begin{tabular}{lrrrrr}
\hline & \multicolumn{2}{c}{ Limit values } & \multicolumn{2}{c}{ Weight $(w)$} \\
\hline Interval & I & II & III & IV & \\
Stability characteristics & 0.25 & 0.5 & 0.75 & 1 & \\
Area of the mother glacier $\left(\mathrm{km}^{2}\right)$ & $<0.5$ & $0.5-1$ & $1-2.5$ & $>2.5$ & 0.07 \\
Distance between lake and glacier $(\mathrm{m})$ & $>600$ & $300-600$ & $80-300$ & $<80$ & 0.27 \\
Slope between lake and glacier $\left(^{\circ}\right)$ & $<12$ & $12-17$ & $17-21$ & $>21$ & 0.22 \\
Mean slope of downstream face of moraine dam $\left(^{\circ}\right)$ & $<10$ & $10-14$ & $14-22$ & $>22$ & 0.195 \\
Mother glacier snout steepness $\left(^{\circ}\right)$ & $<14$ & $14-19$ & $19-26$ & $>26$ & 0.245 \\
\hline
\end{tabular}

susceptibility to outburst is derived from the matrix of its combination (0-6 points).

\section{The study area of the Cordillera Blanca}

\subsection{Deglaciation and lake development in the Cordillera Blanca}

The study area forms part of the high Cordillera Blanca in Peru, the most heavily glacierised tropical range in the world (Ames and Francou, 1995). It is, however, clear that most of the glaciers are retreating. Georges (2004) showed that the total glacial area decreased from $800-850 \mathrm{~km}^{2}$ in 1930 to $600 \mathrm{~km}^{2}$ at the end of the 20th century. It is this intense deglaciation (Fig. 3) that has led to an increasing number of potentially hazardous glacial lakes (bedrock, morainedammed, ice-dammed) (e.g. Hegglin and Huggel, 2008). The number of significant glacial lakes in the region was 230, of which 119 were moraine-dammed, at the beginning of the 1950s (Concha, 1951). These figures had risen to 267 and 148 by the late 1970 s (Morales et al., 1979). It was later found that there were 899 glacial lakes across the region with 424, of which 173 were moraine-dammed, located in the Rio Santa Valley (Portocarrero, 1995). It is now thought that there are more than one thousand glacial lakes in the Cordillera Blanca (A. Cochachin, personal communication, 2012).

It is known that GLOFs have been generated from some of these lakes. The most catastrophic occurred on 13 December 1941 when an aluvión occurred as a result of two moraine ruptures at lakes Palcacocha and Jircacocha. It destroyed one-third of the city of Huaraz (Fig. 4) and claimed about 6000 lives (Lliboutry et al., 1977). This event resulted in a number of glacial lake stability studies that investigated the possibility of further outburst floods in the Cordillera Blanca. Such flooding still occurs despite a range of remedial work that has stabilised more than 30 dams (Reynolds, 2003; Carey, 2005). The three most recent events to have caused damage occurred on 19 May 2003 at Lake Palcacocha in the Cojup Valley (Vilímek et al., 2005b), on 11 April 2010 at lake no. 513 in the Hualcán Valley (Carey et al., 2011), and on the 8 February 2012 at lake Artizon Bajo in the Santa Cruz Valley (A. Cochachin, personal communication, 2012).

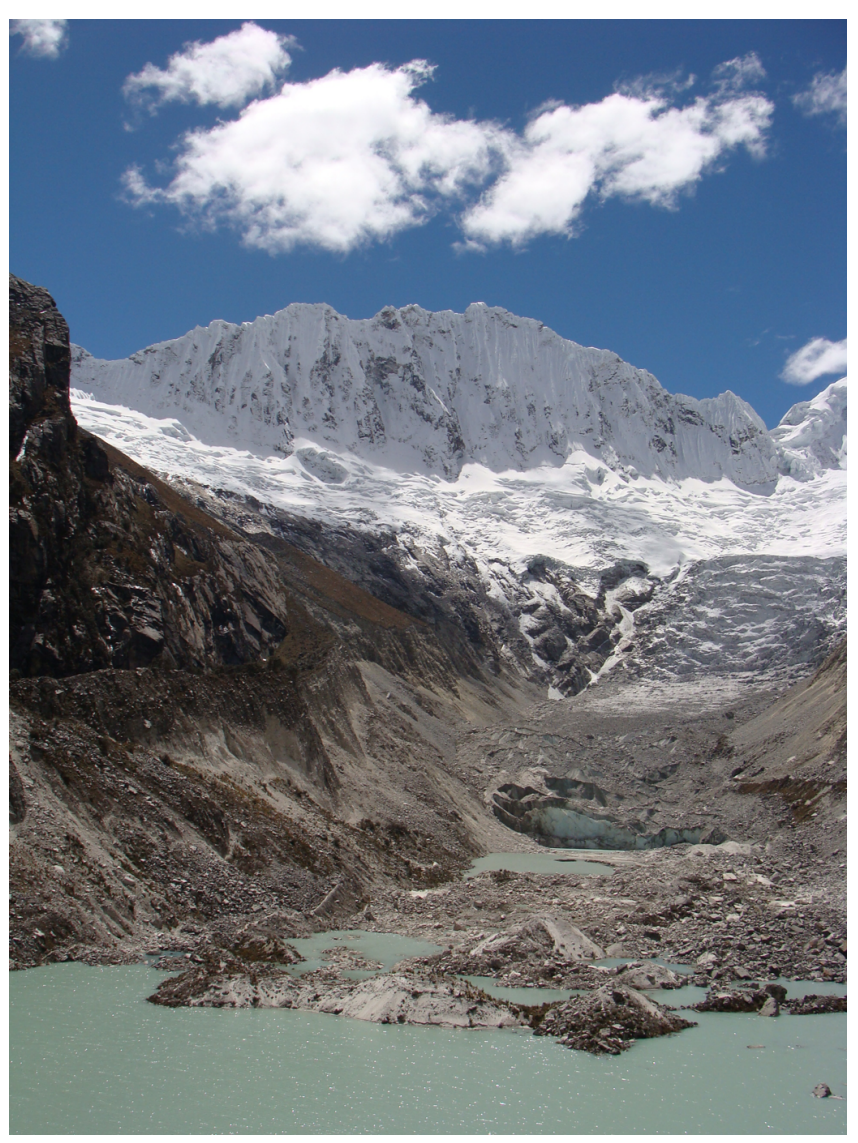

Fig. 3. The growing Lake Llaca with its retreating glacier and protruding basal moraine.

\subsection{The regional specifics of the Cordillera Blanca}

It is necessary to consider the regional specifics in order to accurately define the hazard from moraine-dammed lakes (Hegglin and Huggel, 2008). The GLOF triggers are known to vary considerably across the globe. For example, more than one-third of such floods in the North American Cordillera have been caused by intense rainfall/snowmelt (Clague and Evans, 2000; O'Connor et al., 2001), whereas this trigger has never been recognised in the Cordillera Blanca. In this region the most frequent trigger has been 
Table 8. The assessed stability characteristics and their critical values defined by Mergili and Schneider (2011).

\begin{tabular}{lll}
\hline Stability characteristics (criteria) & Alternatives and critical values & points \\
\hline \multirow{2}{*}{ Topographic susceptibility index (TSI) } & Low $(\mathrm{TSI}<10)$ & 0 \\
& Medium $(10 \leq \mathrm{TSI}<40)$ & 1 \\
\hline Calving into the lake & High $(\mathrm{TSI} \geq 40)$ & 0 \\
\hline \multirow{2}{*}{ Seismic hazard (peak ground acceleration - PGA) $)$} & Low $\left(\mathrm{PGA}<500 \mathrm{~cm} \mathrm{~s}^{-2}\right)$ & 1 \\
\hline \multirow{2}{*}{ Dam freeboard } & High $(\mathrm{PGA} \geq 500 \mathrm{~cm} \mathrm{~s})$ & 0 \\
& High $(F>25 \mathrm{~m})$ & 1 \\
\hline & Low $(F \leq 25 \mathrm{~m})$ & -1 \\
& Embedded lake & 0 \\
\hline Dam material & Block dam & 0 \\
& Debris dam & 0 \\
& Rocky swell dam & 1 \\
\hline Lake drainage & Glacier or fresh moraine dam & 0 \\
\hline \multirow{2}{*}{ Lake area development } & Surface drainage & 2 \\
\hline
\end{tabular}

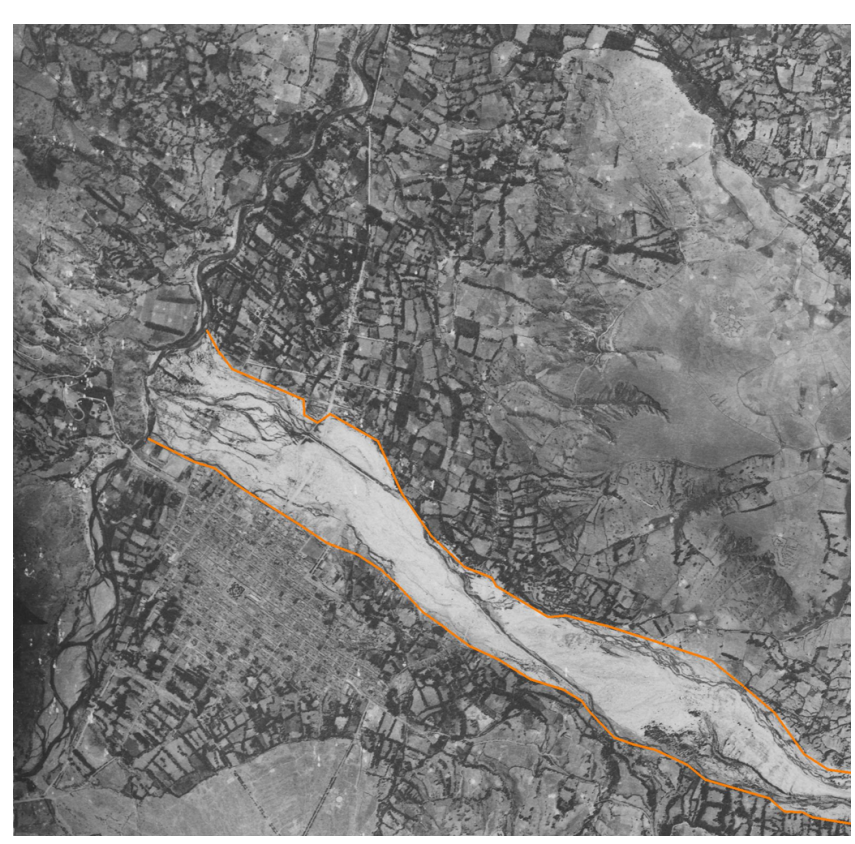

Fig. 4. An aerial photograph of the destroyed city of Huaraz following the aluvion from Lake Palcacocha. The area affected is defined by the orange line; the photograph was taken in 1948, seven years after the flood (Source: INRENA/ANA, Project 2524). icefall into the lake producing displacement waves $(45 \%)$ while the second has been landslides or rockfalls into the lake $(35 \%)$ (Emmer and Cochachin, 2013). Furthermore, in this area, another important trigger is earthquakes as these may initiate mass movements or cause changes to the internal structure of a moraine dam leading to piping and ultimately dam failure. There have also been instances in which an upstream flood wave has propagated downstream and then caused a GLOF (Vilímek et al., 2005b). This mountain range hosts a number of lakes whose dams have been stabilised by a range of remedial work (Reynolds, 2003; Carey, 2005) (Figs. 5 and 6), and such remediation also has to be considered during the hazard assessment.

From the above and from our previous investigations (Vilímek et al., 2005a, b; Emmer and Cochachin, 2013), it is proposed that the most important groups of parameters that should be included in an assessment of the possibility of water release from moraine-dammed lakes in the Cordillera Blanca are the following:

i. The possibility of dynamic slope movement into the lake The first group of dynamic slope movements includes icefalls and avalanches. For a preliminary estimate of whether these slope movements could occur in a lake, it is important to take into account factors such as the distance between the lake and the glacier, the slope between the lake and the glacier, calving, and the slope 


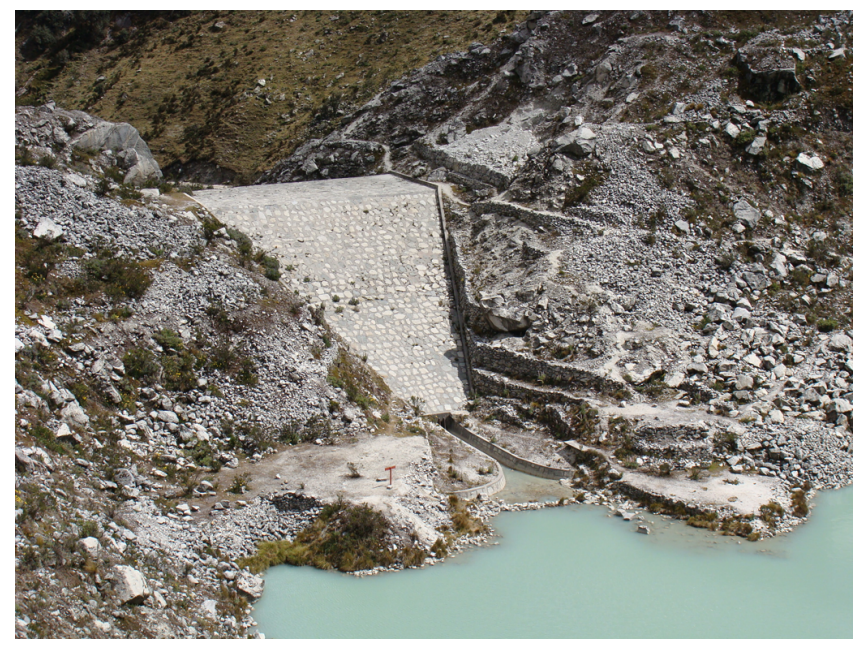

Fig. 5. The artificial dam and armoured outflow of Lake Llaca; the dam freeboard is $12 \mathrm{~m}$.

of the glacier snout. The second group includes landslides, rockfalls, and various types of flows. The most important factors for these movements are thought to be the slope of the internal face of a lateral moraine and the presence of rocks predisposed to rockfalls directly above the lake.

ii. The distinction between natural dams and dams with remedial works

In the case of a natural dam, it is necessary to assess the possibility of a dam breach by, for example, assessing the erodibility of the outflow channel(s), the dam geometry, the occurrence of seepage or piping, and the absence or presence of an ice core. In the case of a dam with remedial work, the type of remedial work (tunnel, artificial dam, open cut or canal) should be considered. If a dam with remedial work is considered to be stable (resistant to erosion), there is still the possibility that it will overflow (for this reason it is important to take into account the dam freeboard).

iii. The dam freeboard (or ratio of dam freeboard)

A sufficiently large dam freeboard (see Fig. 5) eliminates the possibility of dam overflow when slope movements are transported into the lake while artificial dams often provide additional freeboard that has to be included in a hazard assessment. Furthermore, natural dams without surface outflow are able to partially mitigate displacement waves.

iv. The possibility of a flood wave from a lake situated upstream

It may be that a flood wave generated from an upstream lake leads to an outburst flood from a downstream lake even if its dam is considered to be stable and there are no obvious direct triggers (e.g. there is no possibility of

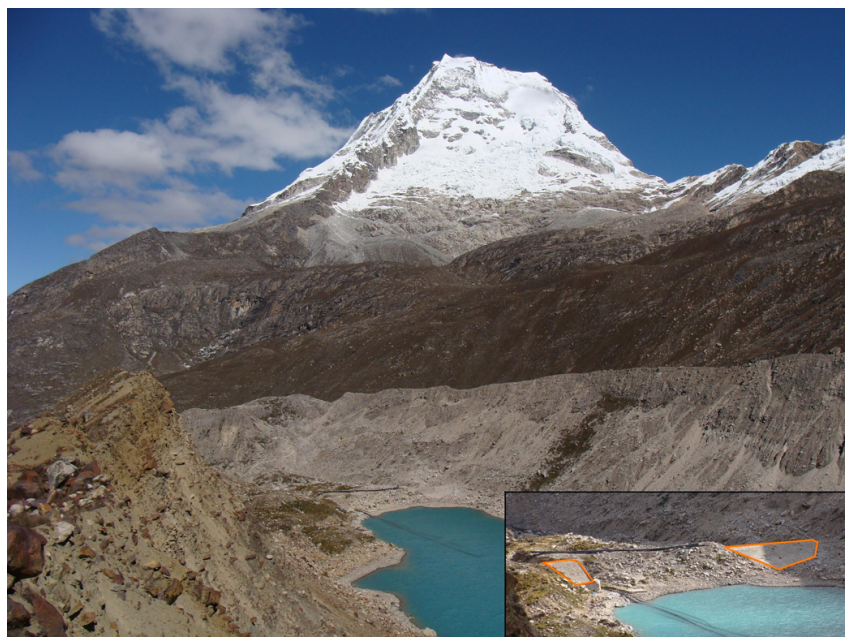

Fig. 6. Lake Palcacocha and its steep lateral moraines, which are predisposed to slope movements, in July 2012. The inset shows the two artificial dams (highlighted in orange) and siphons (black pipes within the lake) constructed during autumn 2011; the dam freeboard is about $9 \mathrm{~m}$.

a slope movement into the lake). It is, therefore, always important to consider the potential threat posed by upstream lakes.

v. The possibility of dam rupture following a large earthquake

The Cordillera Blanca is an active seismic region, and there have been events recorded in which rupture of the moraine dam was initiated by a large earthquake.

\section{Results}

\subsection{The qualitative approach}

The results, presented in Table 9, indicate that none of the selected lakes obtained a "full score" of negative stability parameters following the method presented by O'Connor et al. (2001), which would reflect direct contact with glacier and water outflow over the crest of the moraine. It has been found that two lakes obtained two points while the other four obtained three points from a maximum of four points following the method of Costa and Schuster (1988). The other methods also give scores that oscillate close to $50 \%$ with the exception of that obtained for Lake Rajucolta following the method of Clague and Evans (2000). The highest mean score was obtained for Lake Palcacocha (0.602), and it, therefore, appears to offer the greatest potential for flooding and represents the most hazardous lake. It is notable that a flood occurred from this lake in May 2003, and siphons have since been installed to lower the lake level and increase the dam freeboard (Fig. 6). 
Table 9. The results of the five qualitative methods investigated in this study (total number of investigated parameters in brackets).

\begin{tabular}{|c|c|c|c|c|c|c|c|c|c|c|c|}
\hline \multirow{2}{*}{$\begin{array}{l}\text { Lake } \\
\text { Quitacocha }\end{array}$} & \multicolumn{2}{|c|}{$\begin{array}{c}\text { O'Connor } \\
\text { al. }(2001)(2)\end{array}$} & \multicolumn{2}{|c|}{$\begin{array}{c}\text { Costa and } \\
\text { Schuster (1988) (4) }\end{array}$} & \multicolumn{2}{|c|}{$\begin{array}{c}\text { Clague and } \\
\text { Evans }(2000)(6)\end{array}$} & \multicolumn{2}{|c|}{$\begin{array}{c}\text { Grabs and } \\
\text { Hanisch (1993) (11) }\end{array}$} & \multicolumn{2}{|c|}{$\begin{array}{c}\text { Wang } \\
\text { et al. }(2008)(8)\end{array}$} & \multirow{2}{*}{$\begin{array}{r}\text { Arithmetic } \\
\text { mean } \\
0.474\end{array}$} \\
\hline & $0 / 2$ & 0.00 & $3 / 4$ & 0.75 & $4 / 6$ & 0.67 & $5 / 11$ & 0.45 & $4 / 8$ & 0.50 & \\
\hline Checquiacocha & $1 / 2$ & 0.50 & $3 / 4$ & 0.75 & $3 / 6$ & 0.50 & $5 / 11$ & 0.45 & $4 / 8$ & 0.50 & 0.540 \\
\hline Palcacocha & $1 / 2$ & 0.50 & $3 / 4$ & 0.75 & $3 / 6$ & 0.50 & $7 / 11$ & 0.63 & $5 / 8$ & 0.63 & 0.602 \\
\hline Llaca & $1 / 2$ & 0.50 & $2 / 4$ & 0.50 & $3 / 6$ & 0.50 & $4 / 11$ & 0.36 & $4 / 8$ & 0.50 & 0.472 \\
\hline Rajucolta & $1 / 2$ & 0.50 & $2 / 4$ & 0.50 & $1 / 6$ & 0.17 & $4 / 11$ & 0.36 & $4 / 8$ & 0.50 & 0.406 \\
\hline Tararhua & $1 / 2$ & 0.50 & $3 / 4$ & 0.75 & $3 / 6$ & 0.50 & $5 / 11$ & 0.45 & $5 / 8$ & 0.63 & 0.566 \\
\hline
\end{tabular}

Table 10. The results of the semi-quantitative method defined by Bolch et al. (2011).

\begin{tabular}{lll}
\hline Lake & Result & $\begin{array}{l}\text { Potential } \\
\text { for outburst }\end{array}$ \\
\hline Quitacocha & 0.589 & High \\
Checquiacocha & 0.513 & Medium \\
Palcacocha & 1.042 & High \\
Llaca & 0.612 & High \\
Rajucolta & 0.423 & Medium \\
Tararhua & 0.513 & Medium \\
\hline
\end{tabular}

\subsection{The semi-quantitative approach}

The only semi-quantitative approach used was that of Bolch et al. (2011) as no critical values for an objective lake and breach hazard assessment were defined by Reynolds (2003). It has been found that three of the lakes reflect a medium outburst potential and three a high outburst potential (Table 10). The highest obtained score was that of Lake Palcacocha, mirroring the mean results obtained by the qualitative methods, although its unusually high score may well result from the specific weighting applied as this places considerable emphasis on changes to the lake area. The lowest obtained score was that of Lake Rajucolta again mirroring the mean results obtained by the qualitative methods.

\subsection{The quantitative approach}

The only quantitative approach used was that of Wang et al. (2011). It has been found that all the lakes reflect medium to very high outburst potential (Table 11). The highest obtained score, contradicting the results obtained by the qualitative and semi-quantitative methods, was that of Lake Rajucolta. This is thought to reflect the fact that this method places considerable emphasis on parameters associated with the mother glacier - Lake Rajucolta is in direct contact with the steep slopes of glacier snout, and, therefore, the outburst potential is classified as very high. Moreover, this method does not consider dam stability, and this is considered to be stable due to the sizeable dam freeboard. Lakes Palcacocha and Quitacocha also obtained scores that indicate a very high outburst potential.
Table 11. The results of the quantitative method defined by Wang et al. (2011).

\begin{tabular}{lll}
\hline Lake & Result & $\begin{array}{l}\text { Potential } \\
\text { for outburst }\end{array}$ \\
\hline Quitacocha & 0.843 & Very high \\
Checquiacocha & 0.799 & High \\
Palcacocha & 0.854 & Very high \\
Llaca & 0.585 & Medium \\
Rajucolta & 0.939 & Very high \\
Tararhua & 0.751 & High \\
\hline
\end{tabular}

\section{Discussion}

\subsection{The methods of lake and breach hazard assessment}

The assessment of the possibility of water release from moraine-dammed lakes is associated with certain problems brought about by variability in some of the stability parameters. This variability may be seasonal (e.g. fluctuations in the lake water level) or irreversible (e.g. slope movements). It is also not possible to quantify some of stability parameters, such as the internal dam structure, without undertaking detailed field study (O'Connor et al., 2001).

The outlined methods can all be applied over large areas, and each has specific advantages so that it is not possible to state which is the most appropriate. In general these methods allow a large number of lakes to be assessed using aerial photography, photogrammetry, and satellite-derived data. The data can be analysed rapidly in geoinformation systems and through modelling. It is clear that different researchers assess hazard using different stability parameters, and these are almost always selected subjectively according to the experience of the researcher and the availability of specific data (the exception to this is the statistical study of McKillop and Clague, 2007a, b). Indeed, the methods are all constrained by data availability, and it is generally considered that this is the most significant limiting factor in hazard assessments.

The majority of the stability parameters can be obtained and assessed reasonably accurately from high-resolution remote sensing images or aerial photographs. There are, however, those that cannot, of which the most commonly required relates to the presence or absence of an ice core within the 
Table 12. The methods with regard to whether they take into consideration the regional specifics of the Cordillera Blanca.

\begin{tabular}{llllll}
\hline Method & A & B & C & D & E \\
\hline O’Connor et al. (2001) & Partly & No & Partly & No & No \\
Costa and Schuster (1988) & Yes & No & No & No & No \\
Clague and Evans (2000) & Yes & Yes & Yes & No & No \\
Grabs and Hanisch (1993) & Yes & Partly & Partly & No & No \\
Zapata (2002) & Yes & No & Yes & No & Yes \\
Huggel et al. (2004) & Yes & No & Yes & No & No \\
Wang et al. (2008) & Partly & No & Yes & No & No \\
Hegglin and Huggel (2008) & Yes & Yes & Yes & No & No \\
Bolch et al. (2011) & Yes & No & No & No & No \\
Reynolds (2003) & Partly & No & Yes & No & No \\
Wang et al. (2011) & Partly & No & No & No & No \\
McKillop and Clague (2007a, b) & No & No & No & No & No \\
Mergili and Schneider (2011) & Yes & No & Yes & No & Yes \\
\hline
\end{tabular}

A: possibility of dynamic slope movement into the lake; B: distinction between natural dam and dam with remedial works; C: dam freeboard (or ratio of dam freeboard); D: possibility of flood wave from a lake situated upstream; E: possibility of dam rupture following a large earthquake.

moraine dam. This is an important consideration because it affects dam stability and its internal structure. It cannot be assessed reliably without fieldwork using, for example, ground penetrating radar (Reynolds, 2006) or electric-exploration resistivity (Yamada, 1998). A partial solution may come from the moraine morphology (McKillop and Clague, 2007a), but this is not wholly accurate. In addition, other problematic stability parameters include lake bathymetry, the meteorological regime, the occurrence of piping, and the main rock type forming the moraine. These parameters cannot be determined from remote sensing images, and therefore fieldwork is necessary. It is only with these data that precise hazard assessments for specific lakes can be undertaken. Nonetheless, all of the outlined methods help to recognise potentially hazardous lakes.

The qualitative and semi-quantitative methods include subjective interpretations, and it is thus possible that different researchers may identify different hazards at the same site. The qualitative methods usually have a wide application with no regional focus, whereas the semi-quantitative and quantitative methods frequently focus on specific case studies. These consider the local conditions and causes of GLOFs more carefully than the qualitative methods although some regionally focused methods are replicable in different areas (e.g. McKillop and Clague, 2007a, b). The quantitative approaches are objective and the results are comparable. The characteristics are weighted according to their probable impact on the occurrence of a GLOF or according to their influence on dam stability.

\subsection{Methods of hazard assessment and the regional specifics of Cordillera Blanca}

In Sect. 4.2 we highlighted five groups of parameters that we consider to be crucial for an accurate regionally focused hazard assessment method for moraine-dammed lakes in the Cordillera Blanca. Table 12 shows the extent to which the summarised methods consider these five criteria. The most suitable methods for use in Cordillera Blanca appear to be those presented by Clague and Evans (2000), Zapata (2002), Hegglin and Huggel (2008), and Mergili and Schneider (2011) as they incorporate three of the five criteria.

The majority of the methods incorporate the most common trigger - dynamic slope movements into the lake - although this group of parameters includes both the possibility of icefall or avalanche into the lake as well as the possibility of rockfall or landslide into the lake. If the outlined method only considered one of these possibilities, the term "partly" was applied. In contrast, most of methods do not incorporate the possibility of downstream flood wave propagation nor the possibility of dam rupture following a large earthquake. These groups of parameters are difficult to quantify and assess, but they are known to have caused GLOFs in the Cordillera Blanca and are, therefore, important to include in a regional hazard assessment. The distinction between natural dams and dams with remedial work has only been incorporated into a small number of methods. It is, therefore, necessary to construct a new method that takes into account all the regional specifics of the Cordillera Blanca so as to provide precise lake and breach hazard assessments relating to the moraine-dammed lakes within this mountain range.

\subsection{The results of the lake and breach hazard assessment}

The outlined methods show that potentially the most hazardous of the six lakes is Lake Palcacocha, even though this lake has been remediated. This paper, however, has been written so as to summarise contemporary methods of lake and breach hazard assessment for moraine-dammed lakes 
and discuss their applicability to glacial lakes within the Cordillera Blanca. It has been shown that none of the outlined methods incorporate all of the criteria that we consider crucial for an accurate regional hazard assessment of morainedammed lakes in the Cordillera Blanca. We, therefore, recommend that our results are treated tentatively. For example, the method presented by Clague and Evans (2000) was deemed to be one of the most suitable, and this suggests that Lake Quitacocha may be the most hazardous with a score of 0.67 .

\section{Conclusions}

This paper has summarised 13 methods of lake and breach hazard assessment for moraine-dammed lakes: eight are characterised as qualitative, two as semi-quantitative, and three as quantitative. In total seven of the outlined methods have been used to investigate six moraine-dammed lakes within the Cordillera Blanca. These methods show that most hazardous lake is Lake Palcacocha, which is known to have produced two historical GLOFs (1941 and 2003). The results have been obtained despite the fact that the lake has been remediated. The mean of the five qualitative methods gave a result of 0.602 ; the semi-qualitative method outlined by Bolch et al. (2011) showed a high outburst potential (1.042), whereas the quantitative method outlined by Wang et al. (2011) showed very high outburst potential (0.854). These methods show highly divergent results with regard to Lake Rajucolta. The mean of the five qualitative methods gave a result of 0.406 ; the semi-qualitative method showed only a medium outburst potential ( 0.423$)$, whereas the quantitative method showed the greatest outburst potential (0.939).

The moraine-dammed lakes of the Cordillera Blanca are known to be associated with specific characteristics that differ from a number of other regions affected by GLOFs. It is considered that to produce an accurate method of hazard assessment for the moraine-dammed lakes of this region, it is essential to incorporate the following parameters: the possibility of dynamic slope movements into the lake; the possibility of the downstream propagation of a flood wave; the possibility of dam rupture following a large earthquake; the size of the dam freeboard (or ratio of dam freeboard); and a distinction between natural dams and those with remedial work. It is clear that none of summarised methods incorporate all of these parameters with, at most, three of the five included by Clague and Evans (2000), Zapata (2002), Hegglin and Huggel (2008), and Mergili and Schneider (2011).

It is now important to pay particular attention to the problem of glacial lake outburst floods given global climatic change, glacial retreat, the development of new potentially hazardous glacial lakes, and population growth in the Cordillera Blanca. The possibility of water release from a moraine-dammed lake is both difficult to predict and regionspecific. The first step in effective hazard mitigation and risk management is to reliably define those lakes that are potentially hazardous. It is, therefore, necessary to construct a new regional lake inventory and method of GLOF hazard assessment for the Cordillera Blanca.

Acknowledgements. The authors would like to especially thank Marco Zapata Luyo, Alejo Cochachin, and the staff at the Instituto Nacional de Recursos Naturales/Autoridad Nacional del Agua (Huaraz) for their scientific and logistic support. Bryn Hubbard, Martin Mergli and a third anonymous reviewer are thanked for their valuable comments and recommendations, which helped to improve this work, while the Grant Agency of Czech Republic (Project GACR P 209/11/1000) and Grant Agency of Charles University (Project GAUK No. 70413) provided scientific and financial support.

Edited by: P. Tarolli

Reviewed by: M. Mergili, B. Hubbard, and two anonymous referees

\section{References}

Ames, A. M. and Francou, B.: Cordillera Blanca - glaciares en la historia, Bulletin de l'Institut Français d'Études Andines, 24, 37 64, 1995.

Awal, R., Nakagawa, H., Fujita, M., Kawaike, K., Baba, Y., and Zhang, H.: Experimental study on glacial lake outburst floods due to waves over-topping and erosion of moraine dam, Annals of Disaster Prevention Research Institute, 53, 583-594, 2010.

Bajracharya, B., Shrestha, A. B., and Rajbhandari, L.: Glacial lake outburst floods in the Sagarmatha region, Mountain Res. Develop., 27, 336-344, 2007.

Benn, D. I. and Evans, D. J. A. (Eds.): Glaciers and Glaciation, Hodder Education, London, 1998.

Bolch, T., Buchroithner, M. F., Peters, J., Baessler, M., and Bajracharya, S.: Identification of glacier motion and potentially dangerous glacial lakes in the Mt. Everest region/Nepal using spaceborne imagery, Nat. Hazards Earth Syst. Sci., 8, 13291340, doi:10.5194/nhess-8-1329-2008, 2008.

Bolch, T., Peters, J., Yerogov, A., Pradhan, B., Buchroithner, M., and Blagoveshchensky, V.: Identification of potentially dangerous glacial lakes in the northern Tien Shan, Nat. Hazards, 59, 1691-1714, 2011.

Breien, H., De Blasio, F. V., Elverhøi, A., and Høeg, K.: Erosion and morphology of a debris flow caused by a glacial lake outburst flood, Western Norway, Landslides, 5, 271-280, 2008.

Carey, M.: Living and dying with glaciers: people's historical vulnerability to avalanches and outburst floods in Peru, Global Planet. Change, 47, 122-134, 2005.

Carey, M., Huggel, C., Bury, J., Portocarrero, C., and Haeberli, W.: An integrated socio-environmental framework for glacial hazard management and climate change adaptation: lessons from Lake 513, Cordillera Blanca, Peru, Climatic Change, 112, 733-767, 2012.

Cenderelli, D. A. and Wohl, E. E.: Peak discharge estimates of glacial-lake outburst floods and "normal" climatic floods in the Mount Everest region, Nepal, Geomorphology, 40, 57-90, 2001. 
Clague, J. J. and Evans, S. G.: A review of catastrophic drainage of moraine-dammed lakes in British Columbia, Quaternary Sci. Rev., 19, 1763-1783, 2000.

Concha, J. F.: Origen de las Lagunas, Corporación Peruana del Santa, División de Geología y Seguridad de Lagunas, Huaraz (Peru), 4 pp., 1951.

Costa, J. E. and Schuster, R. L.: The formation and failure of natural dams, Geol. Soc. Am. Bull., 100, 1054-1068, 1988.

Dussaillant, A., Benito, G., Buytaetr, W., Carling, P., Meier, C., and Espinoza, F.: Repeated glacial-lake outburst floods in Patagonia: an increasing hazard?, Nat. Hazards, 54, 469-481, 2009.

Electroperu: Consolidación Laguna Llaca, Electroperu, Huaraz (Peru), 25 pp., 1973.

Electroperu: Proyecto desagüe Laguna Rajucolta, Electroperu, Huaraz (Peru), 96 pp., 1995a.

Electroperu: Desagüe Laguna Tararhua, Electroperu, Huaraz (Peru), 43 pp., 1995 b.

Emmer, A. and Cochachin, A.: Causes and mechanisms of morainedammed lake failures in Cordillera Blanca (Peru), North American Cordillera and Central Asia, AUC Geographica, 48, in press, 2013.

Engel, Z., Šobr, M., and Yerokhin, S. A.: Changes of Petrov glacier and its proglacial lake in the Akshiirak massif, central Tien Shan, since 1977, J. Glaciol., 58, 388-398, 2012.

Evans, S. G.: Climate change and geomorphological hazards in the Canadian Cordillera; the anatomy of impacts and some tools for adaptation, Climate Change Action Fund; Natural Resources Canada, Ottawa (Canada), 21 pp., 2002.

Georges, C.: The 20th century glacier fluctuations in the tropical Cordillera Blanca, Peru, Arctic, Antarctic Alp. Res., 36, 100107,2004

Grabs, W. E. and Hanisch, J.: Objectives and prevention methods for glacier lake outburst floods (GLOFs), in: Snow and Glacier Hydrology (Proceedings of the Kathmandu Symposium, November 1992), Great Yarmouth (UK), 341-352, 1993.

Haeberli, W., Kääb, A., Mühll, D. V., and Teysseire, P.: Prevention of outburst floods from periglacial lakes at Grubengletscher, Valais, Swiss Alps, J. Glaciol., 47, 111-122, 2001.

Harrison, S., Glasser, N., Winchester, V., Haresign, E., Warren, C., and Jansson, K. A.: Glacial lake outburst flood associated with recent mountain glacier retreat, Patagonian Andes, Holocene, 16, 611-620, 2006.

Hegglin, E. and Huggel, C.: An integrated assessment of vulnerability to glacial hazards - a case study in the Cordillera Blanca, Peru, Mountain Res. Develop., 28, 299-309, 2008.

Hewitt, K. J.: Natural dams and outburst floods of the Karakoram Himalaya, in: Hydrological Aspects of Alpine and High Mountain Areas (Proceedings of the Exeter Symposium, July 1982), Great Yarmouth (UK), 259-269, 1982.

Hubbard, B., Heald, A., Reynolds, J. M., Quincey, D., Richardson, S. D., Zapata, M. L., Santillan, N. P., and Hambrey, M. J.: Impact of a rock avalanche on a moraine-dammed proglacial lake: Laguna Safuna Alta, Cordillera Blanca, Peru, Earth Surf. Proc. Landf., 30, 1251-1264, 2005.

Huggel, C., Kääb, A., Haeberli, W., Teysseire, P., and Paul, F.: Remote sensing based assessment of hazards from glacier lake outbursts: a case study in the Swiss Alps, Canadian Geotech. J., 39, 316-330, 2002.
Huggel, C., Haeberli, W., Kääb, A., Bieri, D., and Richardson, S.: An assessment procedure for glacial hazards in the Swiss Alps, Canadian Geotech. J., 41, 1068-1083, 2004.

Iturrizaga, L.: Historical glacier-dammed lakes and outburst floods in the Karamba valley (Hindukush-Karakoram), Geo Journal, 63, $1-47,2005$.

Ives, J. D., Shrestha, B. R., and Mool, P. K.: Formation of glacial lakes in the Hindu Kush-Himalayas and GLOF risk assessment, International Centre for Integrated Mountain Development (ICIMOD), Kathmandu (Nepal), 56 pp., 2010.

Janský, B., Šobr, M., and Yerokhin, S.: Typology of high mountain lakes of Kyrgyzstan with regard to the risk of their rupture, Limnological Rev., 6, 135-140, 2006.

Jiang, Z. X., Cui, P., and Jiang, L.W.: Critical hydrological conditions for overflow burst of moraine lake, Chinese Geogr. Sci., 14, 39-47, 2004.

JTC1 (ISSMGE, ISRM and IAEG Joint Technical Committee on Landslides and Engineered Slopes): ISSMGE TC32 - Technical Committee on Risk Assessment and Management Glossary of risk assessment terms - Version 1, 7 pp., 2004.

Kattelmann, R. and Watanabe, T.: Draining Himalayan glacial lakes before they burst, in: Destructive Water: Water-Caused Natural Disasters, their Abatement and Control (Proceedings of the Conference held at Anaheim, California, June 1996), The Netherlands, 337-343, 1997.

Kershaw, J. A., Clague, J. J., and Evans, S. G.: Geomorphic and sedimentological signature of a two-phase outburst flood from moraine-dammed Queen Bess Lake, British Columbia, Canada, Earth Surf. Proc. Landf., 30, 1-25, 2005.

Klimeš, J.: Geomorphology and natural hazards of the selected glacial valleys, Cordillera Blanca, Peru, AUC Geographica, 47, 25-31, 2012.

Lliboutry, L., Morales, B. A., Pautre, A., and Schneider, B.: Glaciological problems set by the control of dangerous lakes in Cordillera Blanca, Peru, I. Historical failures of moranic dams, their causes and prevention, J. Glaciol., 18, 239-254, 1977.

Lü, R., Tang, B., and Li, D. (Eds.): Introduction of debris flow resulted from glacial lakes failed, in: Debris Flow and Environment in Tibet, Chengdu (China), 69-105, 1999.

Matellini, J.: Conclusiones de la comparación de las fotografías de la Cordillera Blanca año 1948-1962, Corporación Peruana del Santa, Lima, 10 pp., 1965.

McKillop, R. J. and Clague, J. J.: Statistical, remote sensing-based approach for estimating the probability of catastrophic drainage from moraine-dammed lakes in southwestern British Columbia, Global Planet. Change, 56, 153-171, 2007a.

McKillop, R. J. and Clague, J. J.: A procedure for making objective preliminary assessments of outburst flood hazard from morainedammed lakes in southwestern British Columbia, Nat. Hazards, 41, 131-157, 2007b.

Mergili, M. and Schneider, J. F.: Regional-scale analysis of lake outburst hazards in the southwestern Pamir, Tajikistan, based on remote sensing and GIS, Nat. Hazards Earth Syst. Sci., 11, 14471462, doi:10.5194/nhess-11-1447-2011, 2011.

Morales, B. A., Zamora, M. C., and Ames, A. M.: Inventario de lagunas y glaciares del Perú, in: Boletín de la Sociedad Geológica del Perú, Parte III, Lima, 63-82, 1979

Narama, C., Duishonakunov, M., Kääb, A., Daiyrov, M., and Abdrakhmatov, K.: The 24 July 2008 outburst flood at the western 
Zyndan glacier lake and recent regional changes in glacier lakes of the Teskey Ala-Too range, Tien Shan, Kyrgyzstan, Nat. Hazards Earth Syst. Sci., 10, 647-659, doi:10.5194/nhess-10-6472010, 2010.

O'Connor, J. E., Hardison, J. H., and Costa, J. E. (Eds.): Debris flows from failures of Neoglacial-age moraine dams in the Three Sisters and Mount Jefferson Wilderness areas, Oregon, US Geological Survey, Reston (Virginia), 93 pp., 2001.

Petrakov, D. A., Krylenko, I. V., Chernomorets, S. S., Tutubalina, O. V., Krylenko, I. N., and Sakhmina, M. S.: Debris flow hazard of glacial lakes in the Central Caucasus, in: Debris-Flow Hazards Mitigation: Mechanics, Prediction, and Assessment, edited by: Rickenmann, D. and Chen, C., Millpress, The Netherlands, 703714, 2007.

Portocarrero, C. R.: Proyecto prioritario del afianzamiento hídrico del rio Santa, Hidrandina S.A., Huaraz (Peru), 28 pp., 1995.

Quincey, D. J., Richardson, S. D., Luckman, A., Lucas, R. M., Reynolds, J. M., Hambrey, M. J., and Glasser, N. F.: Early recognition of glacial lake hazards in the Himalaya using remote sensing datasets, Global Planet. Change, 56, 137-152, 2007.

Reynolds, J. M.: Development of glacial hazard and risk minimisation protocols in rural environments, Methods of glacial hazard assessment and management in the Cordillera Blanca, Peru, Reynolds Geo-Sciences Ltd., Flintshire (UK), 72 pp., 2003.

Reynolds, J. M.: Role of geophysics in glacial hazard assessment, Environ. Eng. Geosci., 24, 61-66, 2006.

Richardson, S. D.: Remote sensing approaches for early warning of GLOF hazard in the Hindu Kush - Himalayan region, Uniten Nations International Strategy For Disaster Reduction (UN/ISDR), Kathmandu, 35 pp., 2010.

Richardson, S. D. and Reynolds, J. M.: An overview of glacial hazards in the Himalayas, Quaternary Int., 65/66, 31-47, 2000a.

Richardson, S. D. and Reynolds, J. M.: Degradation of ice-cored moraine dams: implications for hazard development, in: DebrisCovered Glaciers (Proceedings of a workshop held at Seattle, Washington, USA, September 2000), The Netherlands, 187-197, 2000b.
Shrestha, A. B.: Managing flash flood risk in Himalaya - information sheet \# 1/10, International Centre for Integrated Mountain Development (ICIMOD), Kathmandu (Nepal), 4 pp., 2010.

Silva, M. L. and Caceres, F. V.: Plan para el control de huaycos y desborde pluviales en la ciudad de Huaraz, Procedimientos de la conferencia internacional sobre desastres naturales, Huaraz (Peru), 2 pp., 1995.

Van Steijn, H.: Debris-flow magnitude-frequency relationships for mountainous regions of central and north-western Europe, Geomorphology, 15, 259-273, 1996.

Vilímek, V., Klimeš, J., and Zapata, M. L.: Glacial lake outburst flood in the areas of Huarás, Cordillera Blanca, Peru, Studia Geomorphologica Carpatho-Balcanica, 39, 115-124, 2005 a.

Vilímek, V., Zapata, M.L., Klimeš, J., Patzelt, Z., and Santillán, N.: Influence of glacial retreat on natural hazards of the Palcacocha Lake area, Peru, Landslides, 2, 107-115, 2005 b.

Wang, W., Yao, T., Gao, Y., Yang, X., and Kattel, D. B.: A firstorder method to identify potentially dangerous glacial lakes in a region of the southeastern Tibetan Plateau, Mountain Res. Develop., 31, 122-130, 2011.

Wang, X., Liu, S., Guo, W., and Xu, J.: Assessment and simulation of glacier lake outburst floods for Longbasaba and Pida lakes, China, Mountain Res. Develop., 28, 310-317, 2008.

WECS (Water and Energy Commission Secretariat): Study of glacier lake outburst floods in Nepal Himalaya, in: WECS Interim Report, Kathmandu (Nepal), 1987.

Worni, R., Stoffel, M., Huggel, C., Volz, C., Casteller, A., and Luckman, B.: Analysis and dynamic modeling of a moraine failure and glacier lake outburst flood at Ventisquero Negro, Patagonian Andes (Argentina), J. Hydrol., 11, 134-145, 2012.

Yamada, T.: Glacier lake and its outburst flood in the Nepal Himalaya, Japanese Society of Snow and Ice, Tokyo, 96 pp., 1998.

Zapata, M. L.: La dinamica glaciar en lagunas de la Cordillera Blanca, Acta Montana, 19, 37-60, 2002. 